\title{
РАЗВЕДЕНИЕ ХИЩНЫХ КЛОПОВ ORIUS ДЛЯ ЗАЩИТЫ РАСТЕНИЙ ОТ ВРЕДИТЕЛЕЙ
}

\author{
Молчанова Е.Д., Баркар В.П., Трибуниова Е. Б. \\ ИТИ «Биотехника» НААНУ,пгт Хлебодарское, Беляевский р-н, Одесская обл., Украина. \\ lentochka.bio@gmail.com;barkarvitalij@gmail.com;093023am@gmail.com
}

\begin{abstract}
Experiments were carried out with Orius laevigatus (Fieber, 1860) from laboratory population. For breeding orius used: reproductive cage; the bowl for the hydroponic garden; the cage for raising the predator; bean plants. Feeding was carried out with pre-frozen eggs of the grain moth. Bean plants with bug eggs remained viable until larvae emerged from them. The largest number of bugs was obtained during the first 14 days.
\end{abstract}

Key words: predatory bug, Orius laevigatus, cages, food, reproduction.

\section{Введение}

Клопы семейства Anthocoridae рода Orius. представляют интерес как агенты биологической защиты растений от вредителей, в частности против трипсов $[1,2,3,4]$. При выращивании в закрытом грунте овощных и цветочных культур трипсы наносят существенный экономический урон тепличным хозяйствам и комбинатам [5, 6, 7]. Также хищники этого вида весьма активно питаются тлями, яйцами и личинками белокрылки, некоторыми видами клещей и уничтожают чешуекрылых на стадии яйца. Высокие плодовитость и прожорливость обеспечивают значительную скорость роста популяции хищника и позволяют в короткий срок снизить численность фитофага даже при высокой исходной плотности его популяции [8].

Самки откладывают яйца только в живые растения под эпидермис, предпочитая жилки и черешки [9, 10]. Основные преимущества ориусов для разведения в искусственных условиях и применения, это короткий цикл развития, способность существовать на растениях в отсутствии животных кормов. что в свою очередь не приносит вреда растениям. Питание происходит соком растений и пыльцой, такой рацион позволяет клопам размножаться, но с меньшей плодовитостью, чем на животных кормах [11]. Ориусы многоядные хищники [12], их широкая пищевая специализация позволяет использовать заменитель природного корма (яйца зерновой моли) для разведения энтомофага, что делает процесс массовой наработки более дешевым и технологичным [8]. У Orius laevigatus (Fieber, 1860), по сравнению с другими представителями этого семейства, отсутствует выраженная диапауза. Эта особенность позволяет круглогодично выращивать клопа в искусственных условиях и применять против вредителей в закрытом грунте [13].

\section{Материалы и методы}

Опыты проводили с O. laevigatus лабораторной популяции. Для разведения ориуса использовали: репродуктивный садок; плошку для гидропонной грядки; садок для выращивания хищника; растения фасоли с 6-8 настоящими листьями, промытый речной песок, замороженные яйца зерновой моли (Sitotroga cerealella, Olivier 1789).

Репродуктивный садок представляет собой прямоугольную емкость из прозрачного пищевого пластика с крышкой. В крышке предусмотрено вентиляционное 
отверстие затянутое ситотканью, также по периметру к крышке прикреплены резиновые уплотнители. В противоположных длинных сторонах садка расположены по 8 отверстий в которые вставлены резиновые втулки с пробирками Флоринского под углом к дну садка (всего 16 пробирок).

Плошка для гидропонной грядки - прямоугольная емкость из непрозрачного пластика. В противоположных длинных сторонах емкости расположено по 4 прорези (всего 8 прорезей). Прорези размещены в «шахматном» порядке с целью обеспечения большего пространства для стеблей и корней растений, размещаемых в плошке.

Садок для выращивания ориуса представляет собой прямоугольную емкость из прозрачного пластика с крышкой в которой предусмотрено вентиляционное отверстие, затянутое ситотканью.

Заморозку яиц зерновой моли и хранение производили в морозильной камере при температуре $-3{ }^{\circ} \mathrm{C}$, не более 10 дней.

Для разведения хищников использовали бокс вивария с контролируемыми климатическими параметрами. Результаты исследований обрабатывались с использованием ПК.

Эксперименты проводили при температуре воздуха $(25 \pm 1){ }^{\circ} \mathrm{C}$ и относительной влажности воздуха $(65 \pm 5) \%$, освещение 16 часов. Повторность опыта - трехкратная.

Растения фасоли были выращены с использованием общепринятых методик. Корни фасоли промывали под проточной водой и укорачивали, а также подрезали верхушки растений и удалили все листья.

В пробирки репродуктивного садка размещали раствор средства с фунгицидным действием и вставляли подготовленные растения фасоли. Также в садок помещали по 1500 взрослых особей ориуса одного времени превращения личинок в имаго. В качестве корма использовали предварительно замороженные яйца зерновой моли. После извлечения из морозильной камеры, перед кормлением, температура корма должна приравниваться к температуре в боксе вивария, где происходит выращивание хищника. Кормление производили каждый день после того как извлекали растения с отложенными яйцами хищника. Для питания одной взрослой особи клопа в сутки необходимо от 7 до 11 яиц в зависимости от их возраста.

Извлеченные из садка растения размещали в плошки для гидропонных грядок и присыпали мокрым песком, производили полив теплой водой. Гидропонные грядки помещали в садки для выращивания клопа. Дополнительно в садки размещали бумажные салфетки и яйца зерновой моли - корм для клопа.

В репродуктивном садке каждый день меняли растения и помещали вместе с гидропонными грядками в садки для выращивания клопов. В них из яиц отрождались личинки, которые впоследствии превращались в имаго (рис. 1). В процессе роста производили кормление личинок (табл. 1).

O. laevigatus в процессе развития

\begin{tabular}{|c|c|}
\hline $\begin{array}{c}\text { Возраст } \\
\text { личинки }\end{array}$ & $\begin{array}{c}\text { Средняя масса яиц, } \\
\text { съеденных 1 особью, мг } \\
\pm \mathrm{SE}\end{array}$ \\
\hline I & $0,164 \pm 0,020$ \\
\hline II & $0,354 \pm 0,012$ \\
\hline III & $0,360 \pm 0,021$ \\
\hline IV & $0,451 \pm 0,050$ \\
\hline V & $0,488 \pm 0,030$ \\
\hline
\end{tabular}


Ежедневно производили подсчет количества особей клопа которые остались в репродуктивном садке, а также подсчитывалось количество имаго, развившееся в садке для выращивания клопов из полученных яиц.

\section{Результаты и обсуждения}

Результаты обработаны и произведен анализ (рис. 1).

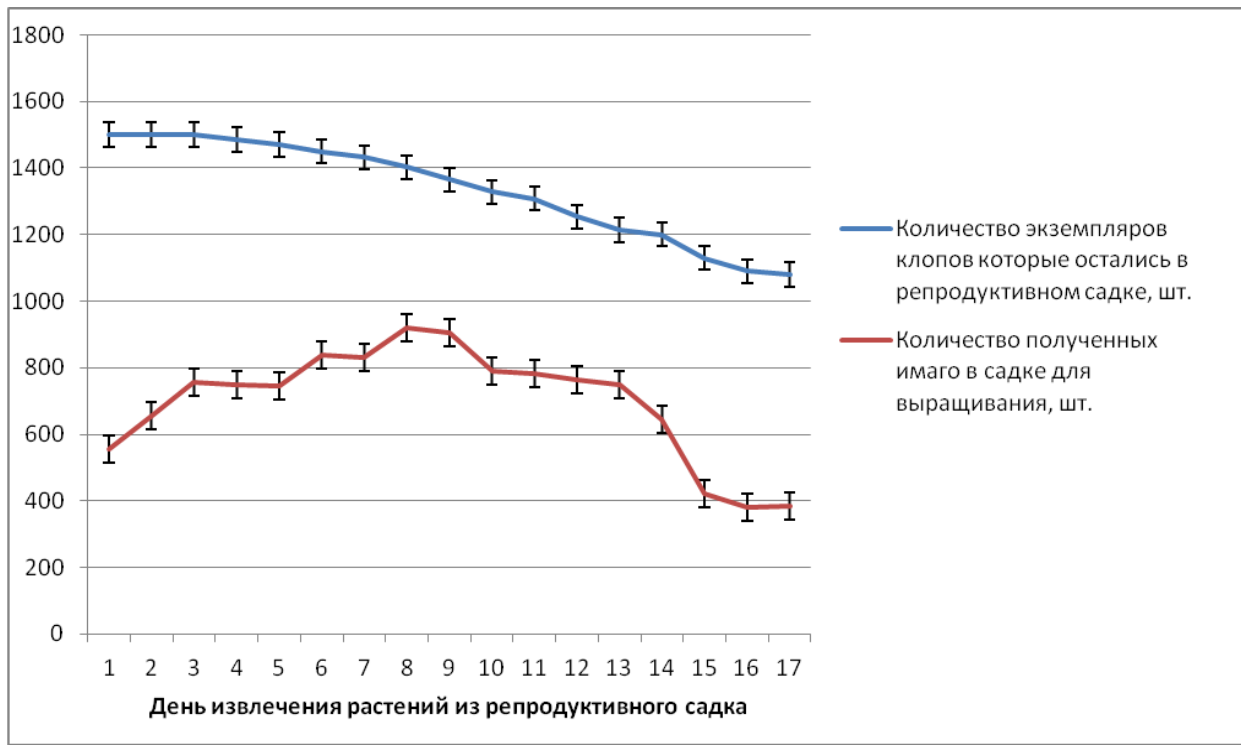

Рисунок 1 - Технологические параметры разведения оріуса в зависимости от дня извлечения растений из репродуктивного садка

Количество имаго, полученных из отложенных в первый день яиц составляло 555 особей. Количество материнских особей на момент откладывания яиц составляло 1500 особей. Максимальная плодовитость ориуса наблюдалась через 8 суток. Количество полученных имаго достигло 919 особей, при этом количество материнских особей в репродуктивном садке сократилось до 1402. На протяжении 14 суток количество полученных клопов превышало изначальный показатель. На четырнадцатый день количество полученных особей составляло 644 штуки. В целом за 14 суток было получено 10681 особи ориуса при оставшихся материнских имаго в количестве 1200 особей. За 17 суток получено 11867 особей. Материнских имаго осталось 1080 штук. Также на 7 сутки наблюдалось увядание растений в гидропонной грядке.

С третьего дня количество материнских особей в репродуктивном садке начало сокращаться. Но, несмотря на это, количество полученных яиц, а следовательно и дочерних имаго увеличивалось и достигло пика на восьмые сутки. То есть, на протяжении этого периода наблюдалось повышение репродуктивных свойств оставшихся в живых особей, которое не только компенсировало естественную убыль материнских имаго, но и способствовало увеличению количества полученного потомства. После указанного срока воспроизводство падало и дальнейшее разведение без добавления материнских имаго было нецелесообразно. 


\section{Выводы}

Изучен процесс разведения хищного клопа ориус. Способ разведения не требует сложного и дорогостоящего оборудования. Предложенные садки удобны в эксплуатации и герметичны.

Определена динамика размножения клопов. В течение восьми суток наблюдался рост воспроизводства с последующим спадом. Наибольшее количество клопов было получено в течение первых 14 дней разведения насекомых. После указанного срока целесообразно пополнять количество материнских особей в садке для получения яиц. Определение количества особей, которое необходимо дополнительно внести в садок для получения яиц, требует дальнейших исследований.

\section{Библиография}

1. Миронова М.К. Методические указания по лабораторному разведению и применению хищного клопа ориуса Orius laevigatus Fieb. - М., 1999, 4 с.

2. Skrivin D.J. The influence of pollen on combining predators to control Frankliniella occidentalis on ornamental chrysanthemum crops // Biocontrol Science and technology, 2006, № 16, p. 99-105.

3. Волков О.Г. Контроль трипсов в закрытом грунте. // Защита и карантин растений, 2006, № 1, С. 23-25.

4. Сапрыкин А.А. Оценка видов клопов сем. Anthocoridae (Heteroptera) для защиты растений в теплице / Мат. ХІІ съезда РЭО (19-24 авг. 2002). - СПб, 2002, с. 4446.

5. Другова Е.В., Варфоломеева В.А. Поставь преграду для проникновения отсут\$ ствующих у нас вредителей. // Защита и карантин растений, 2006, № 2, С. 42-43.

6. Рак Н.С. Особенности биологической защиты растений в оранжереях Заполярья. Автореф. дисс. - СПб, ВИЗР, 2000, 22 с.

7. Sanchez J.A. Garcia M., Conteras J., Gomez Y.J. Response of the Anthocorids Orius laevigatus and Orius albidipennis and the Phitoseids Amblyseius cucumeris for control of Frankliniella occidentalis in commercial crops of sweet peppers in plastics houses in Murcia (Spain). Bull. IOBS/ WPRS. № 4, 1997, p. 177-185.

8. Освоение природных ресурсов хищников-полифагов для использования в биологической защите

9. Сапрыкин А.А., Пазюк И.М. Применение и разведение ориуса. Гавриш. 2003. №3. C.

10. Трапезникова О. В. Оптимизация массового разведения клопов рода Orius. Карантин и защита растений. 2010. №1. С. 48 - 4926 - 29.

11. Kiman Z.B., Yergan K.V. Development and reproduction of the predator Orius insidiosus (Heminoptera: Anthocoridae) reared on diets of selected plant material and Anthropod prey. Annals of the entomological society of America. 1985. № 4. P. 464-467.

12. Чернышов В.Б. Экологическая защита растений. Членистоногие в агроэкосистеме. Москва, МГУ, 2001, 134 с.

13. Красавина Л.П., Трапезникова О. В., Орлова Г. С. Разведение и применение Orius laevigatus против трипсов. Защита и карантин растений. 2013. №2. С. 47 - 48 